\title{
Benthic macroinvertebrate assemblages structure in two headwater streams, south-eastern Brazil
}

\author{
Taynan H. Tupinambás ${ }^{1}$; Marcos Callisto ${ }^{1}$ \& Gilmar B. Santos ${ }^{2}$ \\ ${ }^{1}$ Laboratório de Ecologia de Bentos, Departamento de Biologia Geral, Instituto de Ciências Biológicas, Universidade Federal \\ de Minas Gerais. Caixa Postal 486, 30161-970 Belo Horizonte, Minas Gerais, Brasil. \\ E-mail: taynanh@yahoo.com.br, callisto@icb.ufmg.br \\ 2 Programa de Pós-Graduação em Zoologia de Vertebrados, Pontifícia Universidade Católica de Minas Gerais. \\ 30535-610 Belo Horizonte, Minas Gerais, Brasil. E-mail: astyanax@pucminas.br
}

\begin{abstract}
From December 2003 to September 2004, benthic macroinvertebrates (BM), fishes, water and sediment were collected quarterly at six stations in two streams of the upper São Francisco River basin, south-eastern Brazil. We evaluated the ecological conditions, habitat diversity, water quality, composition and structure of BM communities, as well as the food habits of the local fish fauna. By applying a protocol for rapid characterization of ecological conditions and habitat diversity, three of the sampled localities were classified as "pristine" while the others stations were considered "altered". A well oxygenated water with near neutral pH and low electric conductivity $(<0.01 \mathrm{mS} / \mathrm{cm})$ and nutrient concentrations $(<0.08 \mathrm{mg} / \mathrm{l}$ total $\mathrm{P}$ and $<0.90 \mathrm{mg} / \mathrm{l}$ total $\mathrm{N})$ was found for both streams. Sediment analysis revealed the dominance of medium, fine and very fine sand fractions in all sampled areas. The organic matter content in the sediment was higher in the lotic and well preserved area. We found 45 BM taxa, and Chironomidae (68\%), Oligochaeta (10\%) and Elmidae (8.5\%) showed the highest abundances. From the stomach contents analysis of 13 fish species, 26 BM taxa were found, including four that were not collected in the sediment samples, being Chironomidae the dominant group (>60\%). Our results show that human activities such as forest clearing, agriculture and cattle rising have altered the habitat diversity in freshwater ecosystems in a process that affects the aquatic biota and thus the food availability to the fish fauna. The results also highlight the importance of the fish stomach contents analysis as a complementary tool in BM inventories. KEY WORDS. Bioindicators; ecological conditions; human activities; stomach contents; water quality.
\end{abstract}

RESUMO. Estrutura das assembléias de macroinvertebrados bentônicos em dois córregos de cabeceira no sudeste do Brasil. Entre dezembro de 2003 e setembro de 2004, macroinvertebrados bentônicos (MB) e peixes foram capturados e amostras de água e sedimento foram coletadas trimestralmente em seis pontos de dois córregos de cabeceira da bacia do rio São Francisco. Foram avaliadas as condições ecológicas, diversidade de hábitats, qualidade da água, composição e estrutura das comunidades de $\mathrm{MB}$, bem como sua ocorrência na dieta da ictiofauna local. Três trechos amostrados foram classificados como "naturais" e os demais como "alterados". As águas mostraram-se bem oxigenadas, com $\mathrm{pH}$ próximo ao neutro, com condutividade elétrica $(<0,01 \mathrm{mS} / \mathrm{cm}) \mathrm{e}$ concentrações de nutrientes reduzidas ( $<0,08 \mathrm{mg} / \mathrm{l}$ P-total e $<0,90 \mathrm{mg} / \mathrm{l} \mathrm{N}$-total). Houve predominância das frações de areia média, fina e muito fina no sedimento em todos os trechos, e o teor de matéria orgânica foi maior no trecho lótico melhor preservado. Foram encontrados 45 taxa de MB, sendo Chironomidae (68\%), Oligochaeta $(10 \%)$ e Elmidae $(8,5 \%)$ os mais abundantes. Na análise do conteúdo estomacal de 13 espécies de peixes, obteve-se 26 taxa de $\mathrm{MB}$, quatro destes não encontrados no sedimento, com predomínio de Chironomidade ( $>60 \%$ ). Os resultados sugerem que atividades humanas como desmatamento, agricultura e extração de areia têm alterado a diversidade de hábitats em ecossistemas aquáticos de água doce, em um processo que afeta a biota aquática e consequentemente a disponibilidade de alimento para a ictiofauna. Foi evidenciada também a importância da análise do conteúdo estomacal de peixes como ferramenta complementar em inventários da fauna de MB. PALAVRAS-CHAVE. Atividades antrópicas; bioindicadores; conteúdo estomacal; condições ecológicas; qualidade de água.

Rivers are open dynamic ecosystems whose physic, chemical and biotic characteristics are influenced by anthropic activi- ties taking place in their drainage basin (VANNOTE et al. 1980, AlLAN 1995). Forest clearance and silting are among the main 
processes that affect the environmental quality of drainage basins, favouring the homogenization of the river bed and causing the reduction of habitat diversity and available microhabitats (CALlisto et al. 2005, MoReno \& CALlisto 2006). These factors can affect the communities of aquatic organisms leading to loss of diversity and species extinction (Dudgeon 1996, Primack \& RODRIGUES 2001). Thus, studies on biological communities, associated to the evaluation of habitat diversity and measurements of abiotic parameters, provide a broad picture about land use and occupation and its effects over freshwater ecosystems (JACKson \& Harvey 1993, Pompeu et al. 2005, Casatti et al. 2006).

Brazilian large rivers and reservoirs had been studied more frequently because of their economic importance for fisheries and power production (Esteves \& Aranha 1999). Nevertheless, small-sized rivers and streams share several species with larger ones, being important sites for the reproduction and growth of many aquatic species, especially fishes (BucKup 1999).

In small rivers surrounded with gallery forests, the deposit of fallen leaves, twigs and trunks on the river bed, provides food and shelter for benthic organisms (GonçALVEs et al. 2006a, b). The ability of these organisms to transform vegetal matter and detritus into animal tissues is important for the aquatic food web (Vannote et al. 1980, McCafferty 1981, Allan 1995, Graça 2001). Several benthic macroinvertebrates (BM) taxa, mainly Diptera, are important food items in the diet of the fish fauna (Prejs \& Prejs 1987, Abelha et al. 2001, Williams et al. 2003, Pouilly et al. 2004).

Previous fish studies at the Araguari River basin (Minas Gerais) (CAllisto et al. 2002b), and Manso Reservoir (Mato Grosso) (GALINA \& HAHN 2004), suggest that stomach contents analysis can be used as a tool to evaluate the taxonomic composition and the spatial and temporal distribution of benthic communities, being complementary to biodiversity inventories. Thus, the study of BM communities can be complemented by fish stomach content analysis, especially when information about food availability in the environment is included (ANDRIAN et al. 1994, Deus \& Petrere-Junior 2003).

The aim of this study was to evaluate the structure of BM assemblages in two streams in the upper region of the São Francisco River (SFR) basin, South-eastern Brazil. In order to do so, we evaluated the ecological conditions and habitat diversity, as well as the quality of the water of the two streams. We also estimated the composition and structure of BM communities and analysed its occurrence on the stomachs of the fish fauna.

\section{MATERIALS AND METHODS}

\section{Study area}

The SFR has 2,900 $\mathrm{Km}$ long, draining an extension of $645,000 \mathrm{~km}^{2}$. This river drains six Brazilian states, covering 7.6\% of the country area. From its headwaters to mouth, the river runs trough several Brazilian biomes such as the Cerrado (Brazilian Savanna), the Caatinga (Brazilian drylands) and the Atlantic Forest, also draining some island and shoreline ecosystems (GodinHo \& GodinHo 2003).
The Bagaço stream (10 Km long) is an affluent of the Coelhos stream (20 km long), a sub-basin of the Pará river (300 $\mathrm{Km}$ long) which is one of the most important tributaries at the right margin of the SFR. Thus, both streams are tributaries of $4^{\text {th }}$ and $3^{\text {rd }}$ order respectively, of the upper SFR basin.

Two sampling stations for data collection were delimited at the Bagaço (1A and $1 \mathrm{~B})$ and four at the Coelhos stream (2A, $2 \mathrm{~B}, 3 \mathrm{~A}$ and $3 \mathrm{~B})$. The sampling stations $3 \mathrm{~A}$ and $3 \mathrm{~B}$ were located downstream the confluence of the two water bodies (Fig. 1).

Station $1 \mathrm{~A}\left(20^{\circ} 06^{\prime} 917^{\prime \prime} \mathrm{S}, 4^{\circ} 39^{\prime} 921^{\prime \prime} \mathrm{W}\right)$ : without any vegetal covering, with margins covered by aquatic macrophytes and large areas of still or calm water, being surrounded by pastures and cattle farms.

Station $1 \mathrm{~B}\left(20^{\circ} 05^{\prime} 483^{\prime \prime} \mathrm{S}, 44^{\circ} 39^{\prime} 801^{\prime \prime} \mathrm{W}\right)$ : margins are protected by well preserved gallery forest. The surroundings are mainly pastures and there is an area cleared for sand extraction at the right margin.

Station $2 \mathrm{~A}\left(20^{\circ} 08^{\prime} 086^{\prime \prime} \mathrm{S}, 44^{\circ} 41^{\prime} 192^{\prime \prime} \mathrm{W}\right)$ : gallery forest remains only in the left margin. The stream has areas of still waters intermingled with rapids and is surrounded by pastures and agriculture farms. It also receives the domestic waste produced by a small upstream village.

Station $2 \mathrm{~B}\left(20^{\circ} 05^{\prime} 859^{\prime \prime} \mathrm{S}, 44^{\circ} 40^{\prime} 429^{\prime \prime} \mathrm{W}\right)$ : margins are protected by gallery forest but the surroundings are being heavily cleared for coal production and pasture formation.

Station 3A $\left(20^{\circ} 03^{\prime} 636^{\prime \prime} \mathrm{S}, 44^{\circ} 40^{\prime} 245^{\prime \prime} \mathrm{W}\right)$ : the gallery forest is degraded because of fishing activities and cattle browsing. Pastures at the left margin and agriculture farms at the right margin constitute the surrounding area.

Station 3B $\left(20^{\circ} 01^{\prime} 515^{\prime \prime} \mathrm{S}, 44^{\circ} 40^{\prime} 470^{\prime \prime} \mathrm{W}\right)$ : gallery forest is preserved at the right margin while there are pastures at the left margin. The area is submitted to intensive fishery and agriculture farms are located in its surroundings.

\section{Sampling and data analysis}

Water, sediment and fishes were collected quarterly from December 2003 to September 2004 at every sampling station in order to evaluate water quality, BM communities and fish food items. BM data was analysed in a spatial (among stations) and seasonal (among dry - June and September, and rainy December and March - periods) approach. The biological indexes of water quality were analysed only in a temporal basis. Fish stomach contents were also determined as complement of BM inventory.

\section{Ecological conditions and habitat diversity}

For the characterization of ecological conditions and habitat diversity in the two water courses, we applied the protocol for the rapid characterization of ecological conditions and habitat diversity proposed by CALListo et al. (2002a), where a value is obtained by adding partial values given to each of the parameters independently. The scores indicate the degree of preservation of the sampling stations as follows: 0-40 points, "impacted"; 41-60 points, "altered"; over 61, "pristine". 


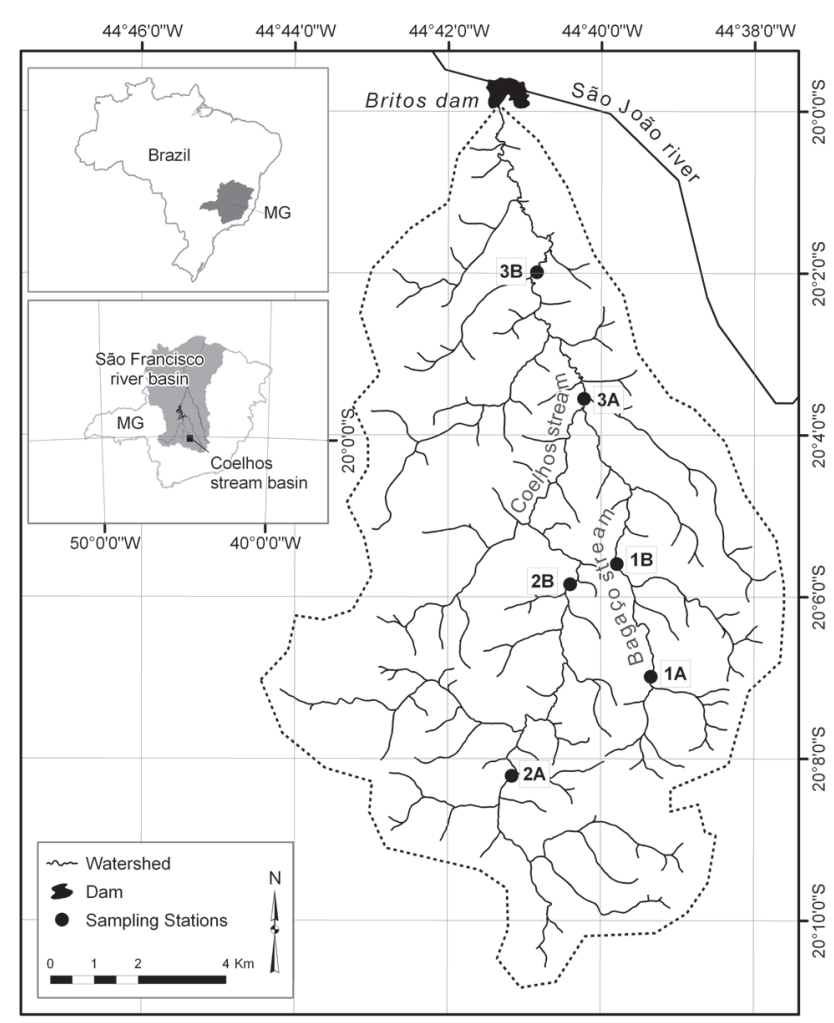

Figure 1. Map of Bagaço and Coelhos streams with sampling stations, São Francisco river basin, Minas Gerais.

\section{Abiotic parameters in the water and sediment}

The variables $\mathrm{pH}$, electrical conductivity and turbidity were measured in the water column using a portable multiprobe (Horiba, model U-10). Water samples were collected and preserved for laboratory analyses. Following the AMERICAN WATER Works Association (1999), the concentration of dissolved oxygen was quantified by Winkler's method, total phosphorus was quantified by SM 4500 P colorimetry, acid digestion and ascorbic acid reaction and total nitrogen was quantified by SM 4500 $\mathrm{N} \mathrm{C}$ colorimetry and persulphate reaction method.

Sediment samples collected using a Van Veen type dredge were used to determine the granulometric composition (SUGUIO 1973, modified by CALListo \& Esteves 1996) and the levels of organic matter (gravimetry).

\section{Microbiological indicators of water quality}

To evaluate water quality for balneability and potability, total and fecal coliforms concentrations were determined by the multiple tube methodology and the density of heterotrophic bacteria was determined by the pour-plate method (AMERICAN Water Works Association 1999).

\section{Benthic macroinvertebrates}

Using a Van Veen dredge (area $=0,045 \mathrm{~m}^{2}$ ), three sediment samples were collected in each sampling station for the analysis of the BM community. The samples were washed in 1.00 and $0.50 \mathrm{~mm}$ mesh sieves and the $\mathrm{BM}$ were retrieved by observation under a stereoscopic microscope. Identification keys in Pérez (1988), Epler (1995), and Merritt \& Cummins (1998) were used for taxonomic identification and the specimens were deposited in the BM reference collection of the Instituto de Ciências Biológicas of the Universidade Federal de Minas Gerais. In order to characterize the structure of BM communities the Shannon diversity index and the Pielou equitability index were calculated following Magurran (2004). Additionally, the density of organisms (ind $/ \mathrm{m}^{2}$ ) was estimated and their relative abundance $\left(\%\right.$ ind $\left./ \mathrm{m}^{2}\right)$ was calculated. The biological indexes of water quality BMWP (Biomonitoring Working Party, adapted by JunqueIra \& CAMPos 1998) and ASPT (Average Score Per Taxa, Johnson et al. 1993) were also calculated.

\section{Fish food items}

Fifty square meters of gill nets with mesh sizes ranging from three to eight $\mathrm{cm}$ between opposing knots (exposed in the water column for 12 hours, since six p.m. to six a.m.) were used for fish collection at each sampling station. Sieves and seine nets were also utilized in order to maximize the number species collected. From 1396 specimens of 29 fish species we analyzed 271 stomach contents of 13 species that: (a) potentially eat BM; (b) $\mathrm{N}>3$. Fish species that do not reach these assumptions were not consider in this study. At the field, a ventral incision was made to the captured specimens that were then fixed in a $10 \%$ formalin solution. At the laboratory, the biometric measurements were made (Standard length \& Weight) and the identification key of BRITSKI et al. (1988) was used for taxonomic identification. Some unidentified fishes were sent to Museu de Ciências e Tecnologia of Pontifícia Universidade Católica of Rio Grande do Sul for taxonomic identification. Stomachs were removed and stored in a $70 \%$ alcohol solution.

The stomachs were dissected and the food items found were separated. The BM found were identified using the same keys mentioned above and quantified using the volumetric and occurrence methods proposed by HysLop (1980). By using these two methods combined it was possible to estimate, for the species with $\mathrm{N}>3$, the Feeding Index (AIi) proposed by KaWAKamI $\&$ Vazzoler (1980): AIi = $($ Fi.Vi) $/ \Sigma$ Fi.Vi, where, $($ Aii) Feeding index of the $i^{\text {th }}$ item; (Fi) frequency of occurrence of the $i^{\text {th }}$ item; (Vi) volume of the $i^{\text {th }}$ item.

\section{Fish stomach analysis for BM inventory}

To evaluate the contribution of the analysis of stomach contents to the characterization of the fauna of BM, the taxonomic inventory obtained by this method and the one obtained by sediment analysis were compared using the Jaccard similarity index (qualitative), following MaGURRAN (2004).

\section{Statistical analysis}

Biotic and abiotic data approved in the normality test (Kolmogorov-Smirnov) were submitted to a parametric statistical analysis using a two-way analysis of variance (ANOVA), 
while data that did not displayed normality were submitted to a generalized non-linear statistical analysis (main effects ANOVA) with Poisson distribution. Software packages Sigmastat 2.03 (Access Softek 1995) and Statistica 7.0 (StATSOFt 2004) were used for the analyses.

\section{RESULTS}

\section{Ecological conditions and diversity of habitats}

Stations $1 \mathrm{~B}, 2 \mathrm{~A}$ and $2 \mathrm{~B}$ were classified as "pristine" while sampling stations $1 \mathrm{~A}, 3 \mathrm{~A}$ and $3 \mathrm{~B}$ were considered "altered". The main parameters of the rapid protocol that affected the results were the presence/absence of gallery forest, the land use in the surroundings and the diversity of habitats and microhabitats (Tab. I).

\section{Abiotic parameters in the water and in the sediment}

In all sampled stations the water was well oxygenated, with near neutral $\mathrm{pH}$ and low electrical conductivity and nutrient concentrations. The highest turbidity values were found at sampling stations $2 \mathrm{~A}, 2 \mathrm{~B}, 3 \mathrm{~A}$ and $3 \mathrm{~B}$, with the maximum value re- corded at 3B. The evaluation of the sediments granulometric composition showed a predominance of medium, fine and very fine sand fractions in all the sampled stations. The highest levels of organic matter in the sediment were measured at 1B (Tab. II).

There were significant differences between dry and rainy periods for the parameters $\mathrm{pH}\left(\mathrm{F}_{(1.5)}=5.720 ; \mathrm{p}<0.05\right)$, water temperature $\left(\mathrm{F}_{(1 ; 5)}=7.6 ; \mathrm{p}<0.05\right)$, and for the fine grain granulometric fraction at the $1 \mathrm{~A}$ station $\left(\mathrm{F}_{(1 ; 5)}=3.538 ; \mathrm{p}<0.05\right)$. For all the other parameters, no spatial or seasonal significant differences were found.

\section{Microbiological indicators of water quality}

The highest values of total and fecal coliforms were found at $1 \mathrm{~A}, 2 \mathrm{~A}, 2 \mathrm{~B}$ and $3 \mathrm{~A}$ sampling stations (> 3000 colonies $/ 100 \mathrm{ml}$ ). The bacterial density was over 2000 UFC up to $500 \mathrm{ml}$ in all sampled stations (Tab. II). No significant differences were found between stations or periods.

\section{Benthic macroinvertebrates}

We collected 9,786 specimens belonging to 45 different taxa. Of these, three belong to the Phylum Mollusca (Planorbidae,

Table I. Characterization of streams ecological conditions and habitat diversity of the São Francisco river basin, Minas Gerais, from December 2003 to September 2004, using Rapid Protocol by CALListo et al. (2002).

\begin{tabular}{|c|c|c|c|c|c|c|}
\hline \multirow{2}{*}{ Parameters } & \multicolumn{2}{|c|}{ Bagaço stream } & \multicolumn{4}{|c|}{ Coelhos stream } \\
\hline & $1^{\mathrm{a}}$ & 1B & $2 \mathrm{~A}$ & $2 B$ & $3 \mathrm{~A}$ & $3 B$ \\
\hline $\begin{array}{l}\text { Type of edge } \\
\text { occupation }\end{array}$ & Grazing fields & $\begin{array}{c}\text { Natural } \\
\text { vegetation }\end{array}$ & Grazing fields & $\begin{array}{c}\text { Natural } \\
\text { vegetation }\end{array}$ & Grazing fields & Grazing fields \\
\hline Erosion & Moderate & Absent & Moderate & Moderate & Moderate & Moderate \\
\hline Anthropic alterations & $\begin{array}{l}\text { Domestic } \\
\text { alterations }\end{array}$ & Absent & $\begin{array}{l}\text { Domestic } \\
\text { alterations }\end{array}$ & $\begin{array}{l}\text { Domestic } \\
\text { alterations }\end{array}$ & $\begin{array}{l}\text { Domestic } \\
\text { alterations }\end{array}$ & $\begin{array}{l}\text { Domestic } \\
\text { alterations }\end{array}$ \\
\hline Vegetal covering & Absent & All & Partial & All & All & Partial \\
\hline Type of sediment & Mud and sand & Rocks and gravel & Mud and sand & Mud and sand & Mud and sand & Mud and sand \\
\hline Mud deposition & $>75 \%$ & $<25 \%$ & $<25 \%$ & $<25 \%$ & $<25 \%$ & $<25 \%$ \\
\hline Instream cover & $\begin{array}{c}10-30 \% \text { of } \\
\text { diversified } \\
\text { habitats }\end{array}$ & $\begin{array}{c}>50 \% \\
\text { diversified } \\
\text { habitats }\end{array}$ & $\begin{array}{l}\text { 30-50\% } \\
\text { diversified } \\
\text { habitats }\end{array}$ & $\begin{array}{c}>50 \% \\
\text { diversified } \\
\text { habitats }\end{array}$ & $\begin{array}{c}30-50 \% \text { diversified } \\
\text { habitats }\end{array}$ & $\begin{array}{l}\text { 30-50\% } \\
\text { diversified } \\
\text { habitats }\end{array}$ \\
\hline Channel alteration & $40-70 \%$ & Absent & $40-70 \%$ & $\begin{array}{l}\text { Absent or } \\
\text { minimum }\end{array}$ & $\begin{array}{l}\text { Absent or } \\
\text { minimum }\end{array}$ & $\begin{array}{l}\text { Absent or } \\
\text { minimum }\end{array}$ \\
\hline $\begin{array}{l}\text { Protective stream bank } \\
\text { vegetation }\end{array}$ & $<50 \%$ & $70-80 \%$ & $<50 \%$ & $70-80 \%$ & $50-70 \%$ & $50-70 \%$ \\
\hline Bank stability & Stable & $\begin{array}{l}\text { Moderately } \\
\text { stable 5-30\% } \\
\text { eroded }\end{array}$ & $\begin{array}{c}\text { Moderately } \\
\text { unstable } 30-60 \% \\
\text { eroded }\end{array}$ & $\begin{array}{l}\text { Moderately } \\
\text { stable } 5-30 \% \\
\text { eroded }\end{array}$ & $\begin{array}{l}\text { Moderately stable } \\
5-30 \% \text { eroded }\end{array}$ & $\begin{array}{l}\text { Moderately } \\
\text { stable 5-30\% } \\
\text { eroded }\end{array}$ \\
\hline $\begin{array}{l}\text { Riparian vegetation } \\
\text { zone width }\end{array}$ & $<6$ meters & $12-17$ meters & $<6$ meters & 6-12 meters & $<6$ meters & $\begin{array}{l}\text { Moderately } \\
\text { stable 5-30\% } \\
\text { eroded }\end{array}$ \\
\hline $\begin{array}{l}\text { Presence of aquatic } \\
\text { vegetation }\end{array}$ & $\begin{array}{l}\text { Presence of } \\
\text { macrophytes }\end{array}$ & $\begin{array}{c}\text { Small } \\
\text { macrophytes } \\
\text { along the river } \\
\text { bed }\end{array}$ & Absent & $\begin{array}{c}\text { Small } \\
\text { macrophytes } \\
\text { along the river } \\
\text { bed }\end{array}$ & $\begin{array}{c}\text { Small macrophytes } \\
\text { along the river } \\
\text { bed }\end{array}$ & $\begin{array}{c}\text { Small } \\
\text { macrophytes } \\
\text { along the river } \\
\text { bed }\end{array}$ \\
\hline Scores & 44 & 82 & 68 & 67 & 59 & 59 \\
\hline Classification & Modified & Natural & Natural & Natural & Modified & Modified \\
\hline
\end{tabular}




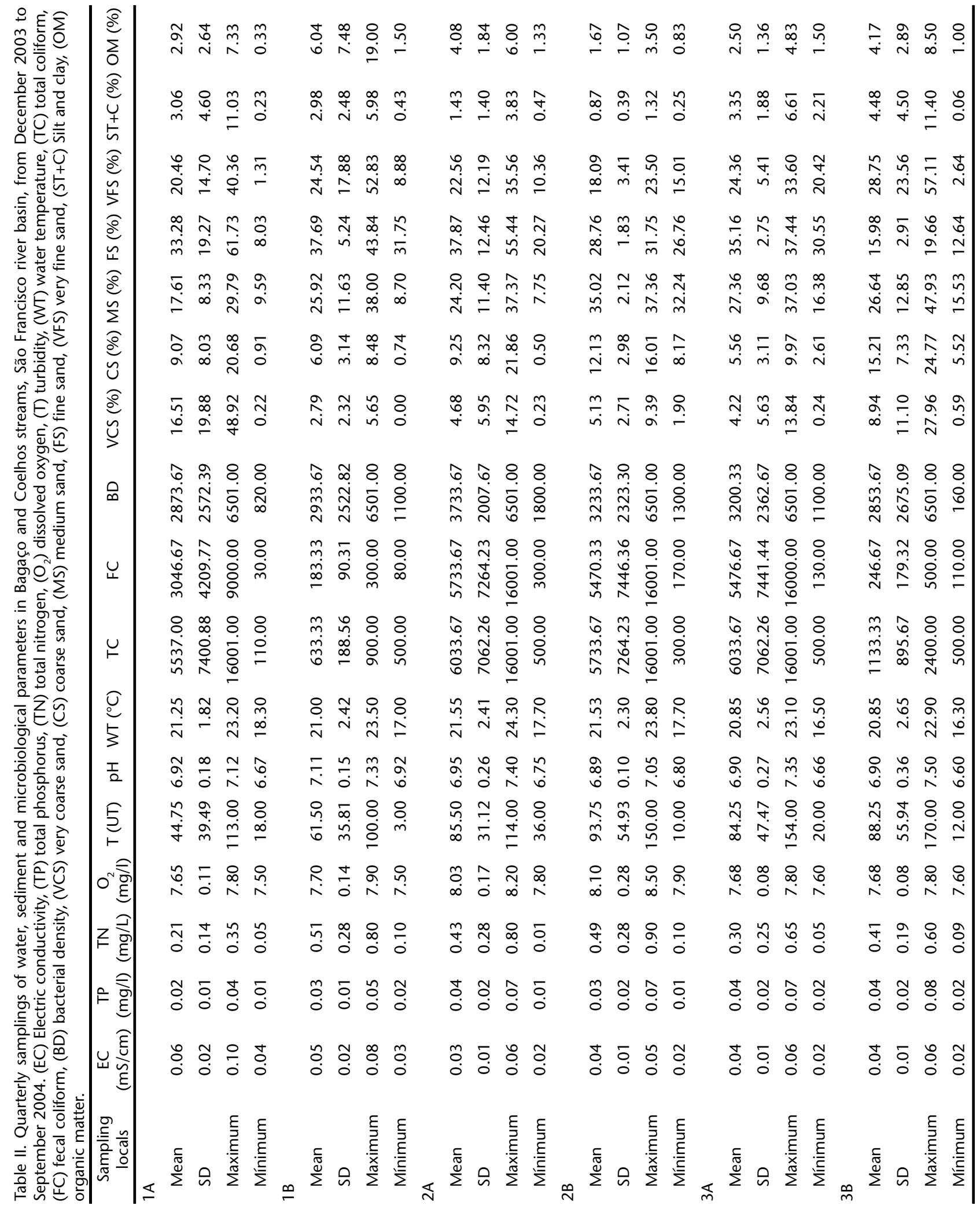


Physidae and Bivalvia), two to the Phylum Annelida (Oligochaeta and Hirudinea) and 40 to the Phylum Artropoda, distributed among Crustacea, Arachnida and Insecta. The nine orders and 37 families of insects were: Plecoptera (Perlidae), Diptera (Ceratopogonidae, Chironomidae, Psychodidae, Simuliidae, Stratiomyidae, Dolichopodidae, Empididae, Tabanidae, Tipulidae), Coleoptera (Elmidae, Scirtidae, Ptilodactylidae, Dryopidae, Dysticidae, Gyrinidae, Hydrophilidae), Ephemeroptera (Polymitarcyidae, Baetidae, Leptophlebiidae, Leptohyphidae), Odonata (Libellulidae, Coenagrionidae, Gomphidae), Trichoptera (Leptoceridae, Hydroptilidae, Polycentropodidae, Calamoceratidae, Odontoceridae, Hydropsychidae), Heteroptera (Belostomatidae, Corixidae, Notonectidae, Naucoridae, Pleidae, Veliidae), Lepidoptera (Pyralidae) and Collembola. Chironomidae, Oligochaeta and Elmidae were the most abundant taxa during both rainy (66, 15 and 8\%) and dry (70, 7 and 9\%) periods.

More taxa were registered for the rainy (38 taxa) than for the dry period (32 taxa). The highest richness values were observed at $2 \mathrm{~B}$ for rainy and at $3 \mathrm{~B}$ for dry period (both with 22 taxa). The lowest values were found at $1 \mathrm{~A}$ during the rainy period (11 taxa) and at 2A during the dry one (9 taxa).

The diversity values were low at all the sampled stations $\left(\mathrm{H}^{\prime}=<2\right)$ with the highest value found at $2 \mathrm{~B}\left(\mathrm{H}^{\prime}=1.9\right)$ during the rainy period, and the lowest at $2 \mathrm{~A}\left(\mathrm{H}^{\prime}=0.6\right)$ during the dry one (Tab. III).

By applying the BMWP and ASPT biological indexes it was possible to determine water quality during the rainy period as "satisfactory" at $1 \mathrm{~A}$, "good" at $1 \mathrm{~B}, 2 \mathrm{~A}, 3 \mathrm{~A}$ and $3 \mathrm{~B}$, and "optimum" at $2 \mathrm{~B}$. During the dry period, the quality of the water was considered "satisfactory" at $1 \mathrm{~A}$ and $2 \mathrm{~A}$, "good" at $2 \mathrm{~B}$ and $3 \mathrm{~A}$ and "optimum" at $1 \mathrm{~B}$ and 3B (Tab. III).

The BM density was significant both between stations $\left(\mathrm{W}_{(1 ; 5)}=45,166 ; \mathrm{p}<0.05\right)$ and sampling periods $\left(\mathrm{W}_{(1 ; 5)}=5,325\right.$; $\mathrm{p}<0.05$ ) (Tabs IV and V), with the highest values found at $1 \mathrm{~B}$ during the dry period. The taxonomic richness was significant only between sampling stations $1 \mathrm{~A}$ and $1 \mathrm{~B}\left(\mathrm{~W}_{(1 ; 5)}=22.44 ; \mathrm{p}<\right.$ 0.05) (Tabs IV and V).

\section{Fish food itens}

From 271 collected specimens, 244 - belonging to 11 families and 13 species - showed some kind of alimentary item
Table III. Density, richness, evenness, diversity, BMWP and ASPT values from benthic macroinvertebrates community and protocol for rapid characterization of ecological conditions for each sampling local, by season, from December 2003 to September 2004, in Bagaço and Coelhos streams, São Francisco river basin, Minas Gerais.

\begin{tabular}{crrrrrr}
\hline $\begin{array}{c}\text { Sampled } \\
\text { season }\end{array}$ & $\begin{array}{c}\text { Density } \\
\left.\text { (ind } / \mathrm{m}^{2}\right)\end{array}$ & $\begin{array}{l}\text { Richness } \\
\left(\mathrm{n}^{\circ} \text { taxa) }\right.\end{array}$ & $\begin{array}{c}\text { Evenness } \\
\text { index }\left(\mathrm{H}^{\prime}\right)\end{array}$ & $\begin{array}{c}\text { BMWP } \\
\text { Rainy }\end{array}$ \\
1A & $3,063.6$ & 11 & 0.6 & 1.3 & 46.0 & 4.2 \\
1B & $33,078.0$ & 17 & 0.6 & 1.5 & 74.0 & 4.4 \\
2A & $16,694.4$ & 18 & 0.5 & 1.2 & 75.0 & 4.2 \\
2B & $18,958.8$ & 22 & 0.8 & 1.9 & 117.0 & 5.3 \\
3A & $16,671.0$ & 17 & 0.6 & 1.3 & 84.0 & 4.9 \\
3B & $16,783.2$ & 15 & 0.6 & 1.4 & 82.0 & 5.5 \\
Dry & & & & & & \\
1A & $2,997.0$ & 13 & 0.7 & 1.5 & 49.0 & 3.8 \\
1B & $22,621.8$ & 19 & 0.8 & 1.6 & 96.0 & 5.1 \\
2A & $24,353.4$ & 9 & 0.9 & 0.6 & 37.0 & 4.1 \\
2B & $19,269.6$ & 16 & 0.7 & 1.6 & 80.0 & 5.0 \\
3A & $28,749.0$ & 14 & 1.0 & 1.4 & 63.0 & 4.5 \\
3B & $22,777.2$ & 22 & 0.7 & 1.8 & 99.0 & 4.5 \\
\hline
\end{tabular}

in their stomach and were analysed. Three species fed mainly on fish: Hoplias lacerdae Miranda Ribeiro, 1908, Hoplias malabaricus (Bloch, 1794) (Erythrinidae) and Salminus hilarii Valenciennes, 1850 (Characidae); two ingested terrestrial plants: Astyanax sp. Baird and Girard, 1854 (Characidae) and Leporinus reinhardti Lütken, 1875 (Anostomidae); four fed on sediments: Hypostomus wuchereri (Günther, 1864) (Loricariidae), Cyphocharax gilbert (Quoy and Gaimard, 1824) (Curimatidae), Geophagus brasilienses (Quoy and Gaimard, 1824) (Cichlidae) and Callichthys callichthys (Linnaeus, 1758) (Callichthyidae); and four used aquatic invertebrates and sediment as main food itens: Gymnotus carapo Linnaeus, 1758 (Gymnotidae), Rhamdia quelen (Quoy and Gaimard, 1824), Pimelodella vittata (Lutken, 1874) (Heptapteridae) and Eigenmannia virescens (Valenciennes, 1842) (Sternopygidae) (Tab. VI).

Table IV. Statistical tests for density and richness among sampled stations, from December 2003 to September 2004, in Bagaço and Coelhos streams, São Francisco river basin, Minas Gerais.

\begin{tabular}{|c|c|c|c|c|c|c|c|c|c|c|}
\hline \multirow{2}{*}{ Parameter } & & \multicolumn{6}{|c|}{ Sampling stations } & \multirow{2}{*}{ DF } & \multirow{2}{*}{ W } & \multirow{2}{*}{$\mathrm{p}$} \\
\hline & & $1 \mathrm{~A}$ & 1B & $2 \mathrm{~A}$ & $2 B$ & $3 \mathrm{~A}$ & $3 B$ & & & \\
\hline \multirow{3}{*}{ Density } & $\mathrm{N}$ & 10 & 12 & 12 & 12 & 12 & 12 & 5 & 45,266 & $<0.05$ \\
\hline & Mean & 606.1 & $6,497.2$ & $3,420.7$ & $3,185.7$ & $3,792.5$ & $3,296.7$ & & & \\
\hline & sd & 605.1 & $7,418.5$ & $4,684.6$ & $3,401.2$ & $3,553.1$ & $2,989.2$ & & & \\
\hline \multirow{3}{*}{ Richness } & $\mathrm{N}$ & 10 & 12 & 12 & 12 & 12 & 12 & 5 & 22.440 & $<0.05$ \\
\hline & Mean & 4.3 & 8.3 & 5.1 & 7.8 & 7.6 & 7.7 & & & \\
\hline & sd & 2.6 & 3.3 & 3.6 & 3.0 & 1.9 & 3.8 & & & \\
\hline
\end{tabular}


Table V. Statistical tests for density and richness among sampling periods, Dry and Rainy, from December 2003 to September 2004, in Bagaço and Coelhos streams, São Francisco river basin, Minas Gerais.

\begin{tabular}{clcccccc}
\hline Parameters & & Rainy & Dry & DF & W & p \\
\hline \multirow{4}{*}{ Density } & N & 34 & 36 & & & \\
& Mean & $3,098.2$ & $3,973.2$ & 1 & 5,325 & $<0.05$ \\
& sd & $3,491.4$ & $5,326.4$ & & & \\
\hline \multirow{4}{*}{ Richness } & $\mathrm{N}$ & 34 & 36 & & & \\
& Mean & 6.6 & 7.2 & 1 & 1,453 & $>0.05$ \\
& sd & 3.4 & 3.3 & & & \\
\hline
\end{tabular}

\section{Fish stomach analysis for BM inventory}

In total, $26 \mathrm{MB}$ taxa were found in the stomach contents of the fishes ( 17 during the rainy period and 24 during the dry period), being 22 of them also found in the sediment samples, Chironomidae was the dominant group found during both periods (> 60\%). Four taxa were exclusively found in the stomach contents (Curculionidae-Coleoptera; Caenidae-Ephemeroptera; Belostomidae-Heteroptera; and Corydalidae-Megaloptera). Similarity of $45 \%$ was observed between the number of taxa found by the analysis of the sediments and stomach contents.

\section{DISCUSSION}

The use of the protocol for the rapid characterization of ecological conditions and habitat diversity evidenced the great influence that anthropic impacts in the surroundings have over the sampling stations. Forest clearance, silting, cattle raising and pasture formation, among others, favoured the homogenization of the bed of both water courses, reducing habitat and microhabitat diversity and thus affecting the biotic compartment of these ecosystems (Dobson 1994, Dudgeon 1996, Primack \& Rodrigues 2001, Aguiar et al. 2002, Callisto et al. 2002a, Boyero \& Bosch 2004, Cassati et al. 2006). The areas with the lowest scores in the characterization protocol also scored low values for the biological indexes of water quality (BMWP and ASPT), as well as low richness and equitability values for benthic organisms. The physical and chemical conditions were homogeneous in relation to the sampled stations during the rainy and the dry periods, suggesting that the same human impacts influence water quality in the studied sub-basins.

The presence of gallery forests is important for the preservation of the margins since it prevents the carriage of sediments to the water courses, as evidenced by the increase in the proportion of the fine sand fraction at the local without any gallery forest coverage $(1 \mathrm{~A})$ during the rainy season. On the other hand, the local with a well preserved gallery forest (1B), showed lower levels of total and faecal coliforms and a greater proportion of organic matter in the sediments.

Based on the water usage by local riverine inhabitants, both water courses are considered to belong to Class II (CONAMA resolution number 357/05), appropriate for human consumption after conventional treatment. However, the values of total and fecal coliforms found during this study are above the established limits for this class (2500 colonies $/ 100 \mathrm{ml})$ at sampling stations $1 \mathrm{~A}, 2 \mathrm{~A}, 2 \mathrm{~B}$ and $3 \mathrm{~A}$, while bacterial density values are above the limits (2000 UFC up to $500 \mathrm{ml}$ ) in all the studied stations.

Vegetal materials as fruits, seeds and other parts of higher plants were the main items in the diet of Astyanax sp. and $L$. reinhardti, however, aquatic invertebrates and detritus were also found in their stomach contents. Similar results were found in other Brazilian localities such as Lobo Reservoir (BARBosa \& Matsumura-Tundisi 1984); São João River basin in Rio de Janeiro State (Bizerril 1996); Caconde lagoon in Rio Grande do Sul State (Hartz et al. 1996); upper SFR (Alvim \& Peret 2004); Atalho stream in Itatinga, São Paulo State (Mota \& Uieda 2004); and Tibagí River in Paraná State (Lobón-Cerviá \& Bennemann 2000, Bennemann et al. 2005). For Leporinus Agassiz, 1829, vegetal matter and invertebrates (ANDrian et al. 1994, Meschiatti 1995, Hahn et al. 1998, BenNemann et al. 2005) as well as insects (DuRães et al. 2001, LuZ et al. 2001) are frequently registered as food in the literature. CALLISTO et al. (2002b) found $86 \%$ of Chironomidae larvae in the stomach contents of Leporinus amblyrhynchus Garavello \& Britski, 1987 at the Miranda Reservoir in the Araguari River basin.

Fish was utilized by $H$. lacerdae, $H$. malabaricus and $S$. hilarii who also feed on aquatic invertebrates, as registered by other studies carried out at the SFR (Pompeu \& Godinho 2003) and the Segredo Reservoir (Paraná) (Loureiro \& HAHN 1996) for H. malabaricus; at SFR (Alvim \& Peret 2004) for Salminus Agassiz, 1829.

Geophagus brasiliensis (Quoy \&Gaimard, 1824) fed mainly on sediments, although aquatic invertebrates and terrestrial plants were also found in the stomach contents. BRITSKI et al. (1988) suggest that Cichlidae ingest sediment that is selected later in the oral cavity. Other authors considered this species omnivorous (SABINO \& CASTRO 1990, BizERRIL 1996). Cyphocharax gilbert fed upon sediment but small quantities of terrestrial plants and aquatic invertebrates were also observed in its diet, in agreement with MérIGOuX \& PONTON (1998) for French Guiana curimatids species. Curimatids are considered detritivorous (Bowen 1984, Gerking 1994). Hypostomus wuchereri fed on algae and sediments (Pompeu \& Godinho 2003, Alvim \& Peret 2004). Loricariidae scratch the substrate in search of their food (BRITSKI et al. 1988, Garavello \& Garavello 2004). Thus, the occurrence of benthic organism in their stomach contents is common. The food itens of $P$. vitatta (Lutken, 1874), R. quelen, G. carapo and $E$. virescens was mainly constituted by benthic invertebrates as described by Mérigoux \& Ponton (1998).

The broad variety of BM (26 taxa) among the food items ingested by the studied fish could be related to ontogenetic and individual variations of the species (Esteves \& AranHA 1999), to seasonal fluctuations in food availability (Prejs \& Prejs 1987, Aвelha et al. 2001) and to human activities carried out in the 
Table VI. Occurrence frequency (F), volume (V) and feeding index (IAi) of food items consumed by fish species sampled quarterly in Bagaço and Coelhos streams, São Francisco river basin, from December 2003 to September 2004. (SL) Standard length in cm, (FI) fish, (TI) terrestrial invertebrates, (Al) aquatic invertebrates, (TP) terrestrial plants, (SD) sediment, (AL) algae, (N) number of analysed fish, (ES) empty stomachs, $\left({ }^{*}\right)$ values below than 0.01 .

\begin{tabular}{|c|c|c|c|c|c|c|c|c|}
\hline \multirow{2}{*}{ Fish species } & \multirow{2}{*}{ SL range } & \multirow{2}{*}{ Parameters } & \multicolumn{6}{|c|}{ Food resources } \\
\hline & & & $\mathrm{FI}$ & $\mathrm{TI}$ & $\mathrm{Al}$ & TP & SD & $\mathrm{AL}$ \\
\hline Astyanax sp. & $7.8-9.8$ & V (\%) & & 4.55 & 13.460 & 80.55 & 0.91 & 0.530 \\
\hline$N=105$ & & $F(\%)$ & & 2.56 & 27.350 & 64.10 & 4.27 & 1.710 \\
\hline $\mathrm{ES}=15$ & & Ali & & * & 0.070 & 0.93 & * & * \\
\hline Callichthys callychthys & $8.4-9.0$ & V (\%) & & & 27.370 & & 72.62 & 0.010 \\
\hline$N=8$ & & $F(\%)$ & & & 46.670 & & 46.67 & 6.670 \\
\hline $\mathrm{ES}=0$ & & Ali & & & 0.270 & & 0.73 & * \\
\hline Cyphocharax gilbert & $9.6-12.5$ & V (\%) & & & 5.220 & 16.40 & 78.38 & \\
\hline$N=13$ & & $F(\%)$ & & & 8.330 & 37.50 & 54.17 & \\
\hline $\mathrm{ES}=0$ & & Ali & & & * & 0.13 & 0.87 & \\
\hline Eigenmannia virescens & $12.5-14.0$ & V (\%) & & & 65.360 & 0.32 & 34.32 & \\
\hline$N=12$ & & $F(\%)$ & & & 50.000 & 4.55 & 45.45 & \\
\hline $\mathrm{ES}=0$ & & Ali & & & 0.680 & * & 0.32 & \\
\hline Geophagus brasiliensis & $8.1-12.0$ & V (\%) & & & 8.670 & 10.56 & 80.77 & \\
\hline$N=18$ & & $\mathrm{~F}(\%)$ & & & 34.290 & 20.00 & 45.71 & \\
\hline$E S=0$ & & Ali & & & 0.070 & 0.05 & 0.88 & \\
\hline Gymnotus carapo & $16.2-22.0$ & V (\%) & & & 27.350 & 5.60 & 67.06 & \\
\hline$N=5$ & & $\mathrm{~F}(\%)$ & & & 45.450 & 18.18 & 36.36 & \\
\hline$E S=1$ & & Ali & & & 0.330 & 0.03 & 0.65 & \\
\hline Hoplias lacerdae & $21.0-35.0$ & V (\%) & 97.970 & & 1.530 & 0.14 & 0.36 & \\
\hline$N=19$ & & $\mathrm{~F}(\%)$ & 50.000 & & 25.000 & 6.25 & 18.75 & \\
\hline$E S=3$ & & Ali & 0.991 & & * & * & * & \\
\hline Hoplias malabaricus & $15.0-20.0$ & V (\%) & 0.990 & & 0.020 & & & \\
\hline$N=11$ & & $\mathrm{~F}(\%)$ & 40.000 & & 60.000 & & & \\
\hline$E S=2$ & & Ali & 0.970 & & 0.030 & & & \\
\hline Hypostomus wuchereri & $9.4-12.3$ & V (\%) & & & & & 42.98 & 57.300 \\
\hline$N=13$ & & $F(\%)$ & & & & & 52.94 & 47.060 \\
\hline$E S=0$ & & Ali & & & & & 0.46 & 0.542 \\
\hline Leporinus reinhardti & $17.5-21.0$ & V (\%) & & & 7.400 & 69.17 & 23.43 & \\
\hline$N=12$ & & $F(\%)$ & & & 40.000 & 30.00 & 30.00 & \\
\hline $\mathrm{ES}=0$ & & Ali & & & 0.10 & 0.68 & 0.23 & \\
\hline Pimelodella vittata & $8.0-9.0$ & V (\%) & 2.360 & & 61.020 & 3.15 & 33.07 & 0.390 \\
\hline$N=5$ & & $F(\%)$ & 8.330 & & 41.670 & 8.33 & 33.33 & 8.330 \\
\hline $\mathrm{ES}=0$ & & Ali & * & & 0.690 & * & 0.30 & * \\
\hline Rhamdia quelen & $16.0-23.0$ & V (\%) & 31.930 & & 43.710 & 1.57 & 22.79 & \\
\hline$N=17$ & & $F(\%)$ & 26.670 & & 43.330 & 10.00 & 20.00 & \\
\hline $\mathrm{ES}=6$ & & Ali & 0.270 & & 0.590 & * & 0.14 & \\
\hline Salminus hilarii & $17.5-22.3$ & V (\%) & 74.690 & & 10.370 & & 14.94 & \\
\hline$N=6$ & & $\mathrm{~F}(\%)$ & 66.670 & & 16.670 & & 16.67 & \\
\hline $\mathrm{ES}=0$ & & Ali & 0.920 & & 0.032 & & 0.05 & \\
\hline
\end{tabular}


surroundings of the studied areas. Deus \& Petrere-Junior (2003) suggest that during the rainy season in tropical regions, fishes tend to be more generalists due to the increase in the variety of available items and also to the reduction of visibility which reduces their capacity to detect their usual prey.

According to Williams et al. (2003), some fish species show feeding preferences for special benthic organisms, independent of their abundance and presence in the sediment. Seasonality and human activities affect the density and richness of BM communities (Bispo \& Oliveira 1998, Callisto et al. 2005), a fact that can justify the feeding plasticity common of freshwater fishes (AвELHa et al. 2001).

The importance of $\mathrm{BM}$ as an autochthonous food resource for fishes in rivers and streams is well documented in the literature (Prejs \& Prejs 1987, Lobon-Cerviá \& Bennemann 2000, Aвelha et al. 2001, Abes et al. 2001, Callisto et al. 2002b, Casatti 2002, Williams et al. 2003, Pouilly et al. 2004).

The BM taxa found in the sediment (45) and the ones found by the analyses of stomach contents (26) showed a median similarity (45\%), evidencing the relationship between the BM available in the sediment compartment and the diet of the fish assemblages. Four of the observed taxa were only found in the stomach contents, complementing the benthic inventory of the studied freshwater systems, and reinforcing the statements by Caluisto et al. (2002b), Russo et al. (2002) and Galina \& HaHN (2004), which suggest that these analyses can contribute to the evaluation of the composition and distribution of BM communities.

Despite the low number of fish studied, the analysis of the stomach contents showed that the use of more than one methodology to access benthic diversity is efficient, enriching the inventory of BM from two headwater streams in the upper SFR basin.

The simultaneous study of different biological communities and their interactions, together with the evaluation of ecological conditions, habitat diversity and abiotic parameters of the water and the sediment, provided an integrate picture on the influence of anthropic activities over drainage basins and their consequences for energy flow and nutrient cycles in freshwater ecosystems.

\section{ACKNOWLEDGEMENTS}

To people that live at the streams areas and the land owners of the sampled areas, to the Graduate Program in Vertebrate Zoology at PUC Minas for the infrastructure and equipments provided; to the SAAE - Itaúna and Viação Itaúna Ltda for human and logistic support; to C.W.C. Branco, L. Casatti and F. Vieira for valuable critics and suggestions on earlier versions of this manuscript; and to D.R. Macedo for drawling the map.

\section{REFERENCES}

Abelha, M.C.F.; A.A. Agostinho \& E. Goulart. 2001. Plasticidade trófica em peixes de água doce. Acta Scientiarum 23 (2): 425-434.
Abes S.S.; A.A. Agostinho \& L.C. Gomes. 2001. Diet of Iheringichthys labrosus (Pimelodidae, Siluriformes) in the Itaipu Reservoir, Paraná River, Brazil-Paraguay. Brazilian Archives of Biology and Technology 44 (1): 101-105.

ACCESS SOFTEK INC. 1995. SigmaStat (statistical software) version 2.03. Avalaible at: http://www.accesssoftek.com [Accessed in 01.VIII.2006].

Aguiar. F.C.; M.T. Ferreira \& P. Pinto. 2002. Relative influence of environmental variables on macroinvertebrate assemblages from na Iberian basin. Journal of the North American Benthological Society 21 (10): 43-53.

AlLAN, J.D. 1995. Structure and function of running waters. London, Chapman \& Hall, 388p.

Alvim, M.C.C. \& A.C. Peret. 2004. Food resources sustaining the fish fauna in a sector of the upper São Francisco river in Três Marias, MG, Brazil. Brazilian Journal of Biology 64 (2): 195-202.

American Water Works Association. 1999. Standard Methods for Examination of Water and Wastewater. Washington, APHA, $20^{\text {th }}$ ed., 1220 p.

Andrian, I.F.; F.A. LANSAC-TôHA \& L.F. Alves. 1994. Entomofauna disponível para alimentação de peixes, comedores de superfície em duas lagoas da planície de inundação do alto rio Paraná, Brasil. Revista UNIMAR 16: 117-126.

Barbosa, P.M.M. \& T. Matsumura-Tundisi. 1984. Consumption of zooplanktonic organisms by Astyanax fasciatus Curvier, 1819 (Osteichthyes, Characidae) in Lobo (Broa) Reservoir, São Carlos, SP, Brazil. Hydrobiologia 113: 171-181.

Bennemann, S.T.; A.M. Gealh; M.L. Orsi \& M.L. Souza. 2005. Ocorrência e ecologia trófica de quatro espécies de Astyanax (Characidae) em diferentes rios da bacia do rio Tibagi, Paraná, Brasil. Iheringia, Série Zoologia 95 (3):247-254.

Bispo, P.C. \& L.G. Oliveira. 1998. Distribuição espacial de insetos aquáticos (Ephemeroptera, Plecoptera e Trichoptera) em córregos de Cerrado do Parque Ecológico de Goiânia, Estado de Goiás, p. 19-33. In: J.L. Nessimian \& A.L. Carvalho (Eds). Ecologia de insetos aquáticos. Rio de Janeiro, PPGE, UFRJ, Série Oecologia Brasiliensis, vol. 5, 309p.

BizerRiL, C.R.S.F. 1996. Estrutura trófica de associações ícticas da bacia do rio São João, RJ. Brazilian Archives of Biology and Technology 39 (3): 509-523.

Bowen, S.H. 1984. Detritivory in neotropical fish communities. Environmental Biology of Fishes 9 (2): 137-144.

Boyero, L. \& J. Bosch. 2004. The effect of riffle-scale environmental variability on macroinvertebrate assemblages in a tropical stream. Hydrobiologia 524: 125-132.

BRITSKi, H.A.; Y. SATo \& A.B.S. Rosa. 1988. Manual de identificação de peixes da região de Três Marias: com chaves de identificação para os peixes da bacia do São Francisco. Brasília: Câmara dos Deputados/Codevasf, $3^{\mathrm{a}}$ ed., 115p.

Buckup, P.A. 1999. Sistemática e biogeografia de peixes de riachos, p. 91-138. In: E.P. Caramashi; R. Mazzoni \& P.R. PerezNeto (Eds). Ecologia de peixes de Riachos. Rio de Janeiro, 
PPGR,UFRJ, Série Oecologia Brasiliensis, vol. 6, 260p.

Callisto, M. \& F.A. Esteves. 1996. Composição granulométrica do sedimento de um lago impactado por rejeito de bauxita e um lago natural (Pará, Brasil). Acta Limnologica Brasiliensia 8: 115-126.

Callisto, M.; M. Goulart; A.O. Mederiros; P. Moreno \& C.A. Rosa. 2005. Diversity assessment of benthic macroinvertebrates, yeasts, and microbiological indicators along a longitudinal gradient in Serra do Cipó, Brasil. Brazilian Journal of Biology 64 (4): 743-755.

Callisto, M.; W. Ferreira; P. Moreno; M.D.C. Goulart \& M. Petrucio. 2002a. Aplicação de um protocolo de avaliação rápida da diversidade de hábitats em atividades de ensino e pesquisa (MGRJ). Acta Limnologica Brasiliensia 13: 91-98.

Callisto, M.; V. Vono; F.A.R. Barbosa \& M.S. Santeiro. 2002b. Chironomidae as a food resource for Leporinus amblyrhynchus (Teleostei: Characiformes) and Pimelodus maculatus (Teleostei: Siluriformes) in a Brazilian reservoir. Lundiana 3 (1): 67-73.

Casatti, L. 2002. Alimentação dos peixes em um riacho do Parque Estadual Morro do Diabo, bacia do alto rio Paraná, sudeste do Brasil. Biota Neotropica 2 (2). Disponível em: http:/ /www.biotaneotropica.org.br/v2n2/pt/abstract?article+ BN02502022002 [Acessado em 01.VIII.2006].

Casatti, L.; F. Langeani; A.M. Silva \& R.M.C. Castro. 2006. Stream fish, water and habitat quality in a pasture dominated basin, Southeastern Brazil. Brazilian Journal of Biology 66 (2B): 681: 696 .

Deus, C.P. \& M. Petrere-Junior. 2003. Seasonal diet shifts of seven fish species in an Atlantic Rainforest stream in Southeastern Brazil. Brazilian Journal of Biology 63 (4): 579-588.

Dobson, M. 1994. Microhabitat as a determinant of diversity: stream invertebrates colonizing leaf packs. Freshwater Biology 32: 565-572.

Dudgeon, D. 1996. Anthropogenic influences on Hong Kong streams. Geo-journal 40 (1-2): 53-61.

Durães, R.; P.S. Pompeu \& A.L. Godinho. 2001. Alimentação de quatro espécies de Leporinus (Characiformes, Anostomidae) durante a formação de um reservatório no sudeste do Brasil. Iheringia, Série Zoologia 90: 183-191.

EPLer, J.H. 1995. Identification manual for the larval Chironomidae (Diptera) of Florida. Orlando, Department of Environment Protection of Florida, 450p.

Esteves, K.E. \& J.M.R. Aranha. 1999. Ecologia trófica de peixes de riachos, p. 157-182. In: E. P. Caramashi; R. Mazzoni \& P.R. Perez-Neto (Eds). Ecologia de peixes de riachos. Rio de Janeiro, PPGR, UFRJ, Série Oecologia Brasiliensis, vol. 6, 260p.

Galina, A.B. \& N.S. Hahn. 2004. Atividade de forrageamento de Triportheus spp. (Characidae, Triportheinae) utilizada como ferramenta de amostragem da entomofauna, na área do reservatório de Manso, MT. Revista Brasileira de Zoociências 6 (1): 81-92.

Garavello, J.C. \& J.P. Garavello. 2004. Spatial distribution and interaction of four species of the catfish genus Hypostomus lacépède with bottom of Rio São Francisco, Canindé do São Francisco, Sergipe, Brazil (Pisces, Loricariidae, Hypostominae). Brazilian Journal of Biology 64 (3b): 103-141.

Gerking, S.D. 1994. Feeding ecology of fish. San Diego, Academic Press, $416 \mathrm{p}$.

Godinho, A.L. \& H.P. Godinho. 2003. Breve visão do São Francisco, p. 15-24. In: H.P. Godinho \& A.L. Godinho (Eds). Águas, peixes e pescadores do São Francisco das Minas Gerais. Belo Horizonte, PUC Minas, 468p.

Gonçalves Jr, J.F.; J.S. França; A.O. Medeiros; C.A. Rosa \& M. Callisto. 2006a. Leaf breakdown in a tropical stream. International Review of Hydrobiology 91: 164-177.

Gonçalves Jr, J.F.; M.A.S. Graça \& M. Callisto. 2006b. Leaf-litter breakdown in 3 streams in temperate, Mediterranean, and tropical Cerrado climates. Journal of the North American Benthological Society 25 (2): 344-355.

Graça, M.A.S. 2001: The role of invertebrates on leaf litter decomposition in stream-a review. International Review of Hydrobiology 86: 383-393.

Hahn, N.S.; A.A. Agostinho; L.C. Gomes \& L.M. Bini. 1998. Estrutura trófica da ictiofauna do reservatório de Itaipú (ParanáBrasil) nos primeiros anos de sua formação. Interciência 23 (5): 299-305.

HartZ, S.M.; C.M. Silveira. \& G. Barbieri. 1996. Alimentação das espécies de Astyanax Baird \& Girard, 1894 ocorrentes na lagoa Caconde, RS, Brasil (Teleostei, Characidae). Revista UNIMAR 8 (2): 269-281.

Hyslop, E.J. 1980. Stomach contents analysis - a review of methods and their application. Journal of Fish Biology 17: 411-429.

JACKSON, D.A. \& H.H. HaRvey. 1993. Fish and benthic macroinvertebrates: community concordance and community-environment relationships. Canadian Journal of Fisheries and Aquatic Sciences 50: 2641-2651.

Johnson, R.K.; T. Wielderholm \& D.M. Rosenberg. 1993. Freshwater biomonitoring using individual organisms, populations, and species assemblages of benthic macroinvertebrates, p. 40-158. In: D.M. Rosenberg \& V.H. RESH (Eds). Freshwater biomonitoring and benthic macroinvertebrates. New York, Chapman and Hall, 488p.

Junqueira, V.M. \& S.C.M. Campos. 1998. Adaptation of the "BMWP" method for water quality evaluation to Rio das Velhas watershed (Minas Gerais, Brazil). Acta Limnologica Brasiliensia 10 (2): 125-135.

Kawakami, E. \& G. Vazzoler. 1980. Método gráfico e estimativa de índice alimentar aplicado ao estudo de alimentação de peixes. Boletim do Instituto Oceanográfico 29 (2): 205207.

Lóbon-Cervia, J. \& S. Bennemann. 2000. Temporal trophic shifts and feeding diversity in two synpatric, neotropical omnivorous fishes: Astyanax bimaculatus and Pimelodus maculatus in rio Tibagi (Paraná, Southern Brazil). Archiv für Hydro- 
biologie 149 (2): 285-306.

Loureiro, V.E. \& N.S. Hahn. 1996. Dieta e atividade alimentar da traíra Hoplias malabaricus (Block, 1794) (Osteichthyes, Erythrinidae) nos primeiros anos de formacão do Reservatório de Segredo. Acta Limnologica Brasiliensia 8: 195205.

Luz, K.D.G.; F. Abujanra; A.A. Agostinho \& L.C. Gomes. 2001. Caracterização trófica da ictiofauna de três lagoas da planície aluvial do alto rio Paraná, Brasil. Acta Scientiarum 23 (2): 401-407.

MagurRan, A.E. 2004. Measuring biological diversity. Oxford, Blackwell Science, 256p.

MCCAFferty, W. 1981. Aquatic Entomology. The fishermen's and ecologist's illustred guide to insects and their relatives. Boston, Jones and Barlett, 448p.

Mérigoux, S. \& D. Ponton. 1998. Body shape, diet and ontogenetic diet shifts in young fish of the Sinmnamary River, French Guiana, South America. Journal of Fish Biology 52: 556569.

Merritt R.W. \& K.W. Cummins. 1998. An introduction to the aquatic insects of North America. Iowa, Kendall/Hunt, $2^{\text {nd }}$ ed., 750p.

Meschiatti, A.J. 1995. Alimentação da comunidade de peixes de uma lagoa marginal do rio Mogi-Guaçu, SP. Acta Limnologica Brasiliensia 7: 115-137.

Moreno, P. \& M. Callisto. 2006. Benthic macroinvertebrates in the watershed of an urban reservoir in southeastern Brazil. Hydrobiologia 60: 311-321.

MotTa, R.L. \& V.S. Uieda. 2004. Dieta de duas espécies de peixes do Ribeirão do Atalho, Itatinga, SP. Revista Brasileira de Zoociências 6 (2): 191-205.

Pérez, G.R. 1988. Guía para el estudio de los macroinvertebrados acuáticos del Departamento de Antioquia. Bogotá, Fondo Fen Colombia, Colciencias, Universidad de Antioquia, 217p.

Pompeu, P.S \& H.P. Godinho. 2003. Dieta e estrutura trófica das comunidades de peixes de três lagoas marginais do médio São Francisco, p. 183-194. In: H.P. GodinHo, \& A.L. GodinHo. (Eds). Águas, peixes e pescadores do São Francisco das
Minas Gerais. Belo Horizonte, PUC Minas, 468p.

Pompeu, P.S.; C.B.M. Alves \& M. Callisto. 2005. The effects of urbanization on biodiversity and water quality in the Rio das Velhas basin, Brasil. American Fisheries Society Symposium 47: 11-22.

Poullly, M.; T. Yunoki; C. Rosales \& L. Torres. 2004. Trophic structure of fish assemblages from Mamoré River floodplain lakes (Bolivia). Ecology of Freshwater Fish 13: 245-257.

Prejs, A. \& K. Prejs. 1987. Feeding of tropical freshwater fishes: seasonality in resource availability and resource use. Oecologia 71: 397-404.

Primack, R.B. \& E. Rodrigues. 2001. Biologia da Conservação. Londrina, Editora Viva, 328p.

ConAma. 2005. Resolução $\mathbf{n}^{\mathbf{o}}$ 357/2005 - "Dispõe sobre a classificação dos corpos de água e diretrizes ambientais para o seu enquadramento, bem como estabelece as condições e padrões de lançamento de efluentes, e dá outras providências." - Data da legislação: 17/03/2005. Brasília, Diário Oficial da União de 18.III.2005.

Russo, M.R.; A. Ferreira \& R.M. Dias. 2002. Disponibilidade de invertebrados aquáticos para peixes bentófagos de dois riachos da bacia do rio Iguaçu, Estado do Paraná, Brasil. Acta Scientiarum 24 (2): 411-417.

SABINO, J. \& R.M.C. CASTRO. 1990. Alimentação, períodos de atividade e distribuição espacial dos peixes de um riacho da floresta Atlântica (sudeste do Brasil). Revista Brasileira de Biologia 50: 23-36.

Statsoft Inc. 2004. Statistica (data analysis software system), version 7.0. Tulsa, available at: http://www.statsoft.com [Accessed in 01.VIII.2006].

SuguIO, K. 1973. Introdução à Sedimentologia. São Paulo, Ed. Edgard Blucher, 317p.

Vannote, R.L.; G.W. Minshall; K.W. Cummins; J.R. Sedell \& C.E. Cushing. 1980. The river continuum concept. Canadian Journal of Fisheries and Aquatic Sciences 37: 130-137.

Williams, L.R.; C.M. TAYlor \& M.L. WarRen. 2003. Influence of fish predation on assemblage structure of macroinvertebrates in an intermittent stream. Transactions of the American Fisheries Society 132: 120-130.

Received in 28.IX.2006; accepted in 08.XI.2007. 